\title{
Zakat collection and distribution system and its impact on the economy of Indonesia
}

\author{
Muhtadi Ridwan ${ }^{a^{*}}$, Nur Asnawi ${ }^{\mathrm{a}}$ and Sutikno ${ }^{\mathrm{a}}$
}

${ }^{a}$ Maulana Malik Ibrahim State Islamic University, Indonesia

\begin{tabular}{l}
\hline C H R O N I C L E \\
\hline Article history: \\
Received May 6, 2019 \\
Received in revised format May \\
19,2019 \\
Accepted June 12019 \\
Available online \\
June 12019 \\
\hline Keywords: \\
Zakat collection and distribution \\
Economic growth \\
Supply chain \\
Indonesia
\end{tabular}

\section{Introduction}

For the economic development and growth in Islamic economy, zakat is playing its own significant role (Yusoff, 2011). The reason is that funds collected from zakat help the community who are financially under pressure (Ali \& Hatta, 2014). In this regard, payment of zakat is an obligation for those Muslims who have excessive wealth up to a specific limit as prescribed by Shariah laws (Kuran, 1986; Lewis, 2001). Several benefits have been observed through zakat system in the community like minimizing the gap between rich and poor, provision of various facilities like health, education, transportation and other necessities of those who are not under good financial conditions (Sarea, 2012; Suprayitno et al., 2017; Yusoff, 2011). For the management of zakat, various systems have been adopted in the world's economy. For instance, from the context of Malaysia, it is the obligation of each state to collect the zakat funds (Rahim \& Rahman, 2007). In this regard, the role of Indonesian agency

\footnotetext{
* Corresponding author

E-mail address: rid one1905@yahoo.com (M. Ridwan)

C 2019 by the authors; licensee Growing Science.

doi: $10.5267 /$ j.uscm.2019.6.001
} 
is significant which is responsible for collecting and distributing zakat payments to the needy people in the local community (Bakar \& Abdghani, 2011; Havidz \& Setiawan, 2015; Ali et al., 2016; Hammoud \& Bittar, 2016; Bittar, 2017; Javaid \& Alalawi, 2018; Hassan \& Alanazi, 2018).

Considering the economy of Indonesia, as per the findings of Sudibyo (2017) to reduce the poverty in the country, contribution of zakat payments is very much significant. As the country of Indonesia is the biggest in terms of Muslim community with almost 85 percent of the local individuals belong to the religion of Islam, huge funds are collected in the form of zakat from such community. Fig. 1 below provides an outlook for the total billion Rupiah, million US dollars, annual growth in percentage and GDP growth in percentage in the economy of Indonesia. It is found that from 2002 to 2015, there wa an increase of 5310 percent and over the period 2005-2007, the increase in zakat collection and payment was more than 100 percent (Sudibyo, 2017). The reason is that during these years, country was faced with the biggest disaster in the form of Tsunami which had targeted the major areas. However, from 2002 to 2015, an average increasing of 39.28 percent was observed. In addition, collection of zakat, Infaq and Sadaqah has also shown to be higher than the GDP growth rate during the year of 2009. Meanwhile due to global financial crisis, GDP growth rate was declined from 1.3 percent, whereas growth rate of zakat has been increased to 6.11 percent (Sudibyo, 2017).

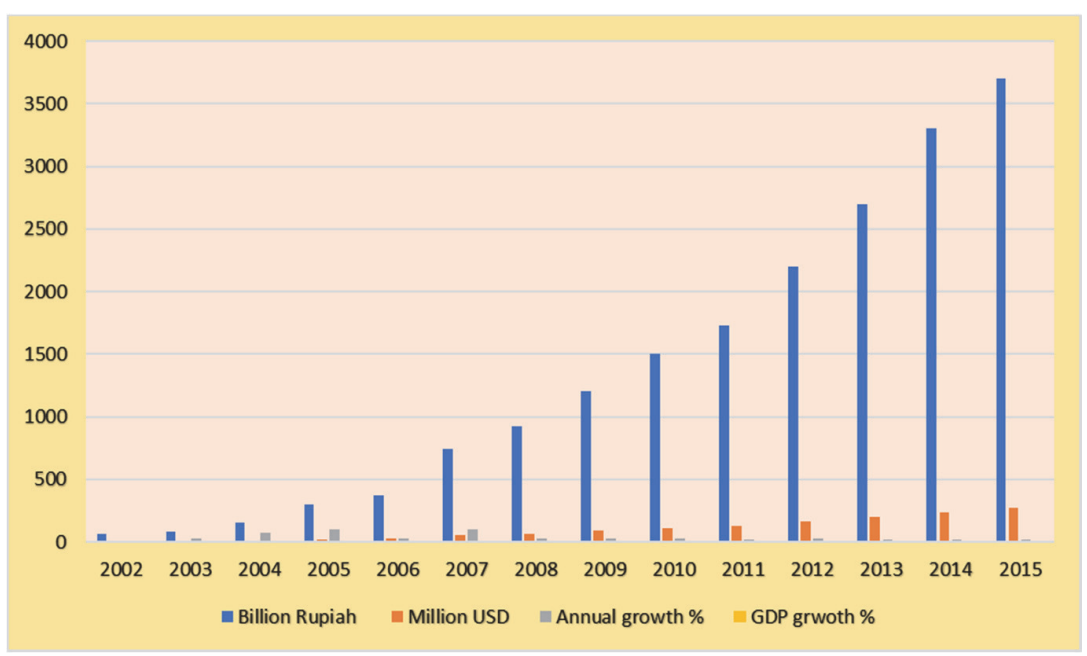

Fig. 1. Time Series Graphs of Zakat, infaq and sadaqah in Indonesia Source: (Sudibyo, 2017)

The present study considers the factor of zakat collection and zakat distribution as two key dimensions of supply chain perspective in Islamic finance to examine their economic impacts in Indonesia. To the best of author's findings, this study is the first attempted for examining the interaction between zakat collection and distribution with economic outcomes. The rest of the study is as follows. Section two is devoted to the literature review, which is mostly from the context of ASEAN region like Malaysia and Indonesia. Section three covers methods, variables and sample of the study. Section four provides empirical and descriptive findings and their discussion. Last section covers the conclusion and future recommendations of the study.

\section{Literature Review}

There are various studies explored the idea of zakat collection and distribution in different economies of the world. For instance, Zainal et al. (2016) explain that zakat is among the five basic pillars of Islam and considers it as basic obligation for the Muslims. They explain that zakat plays its major role to alleviate the poverty and to minimize the gap between rich and poor. In this regard, authors discus three key factors of reputations, satisfaction and quality of services to affect the stakeholders' trust in zakat institutions in the region of Malaysia. While research work conducted by Kaslam (2009) empirically 
investigates the governance of zakat as social institute in Malaysia as well. Author has claimed the fact the zakat management system must be integrated with the courtesy, plan of integrity, loyalty and as social institutions for the better growth and economic output. In addition, Ahmad and Ma'in (2014) examine the efficiency of zakat collection and distribution through two stage analysis, for this purpose, data envelopment analysis model is utilized for the collection and distribution of zakat along with technical efficiency of the model. Meanwhile, overall efficiency and cost benefit analysis reveals the fact that there is a presence of cost minimization with the proper output from the resources through better utilization. Some other studies also provide their theoretical and empirical contributions in the field of Islamic finance for zakat distribution and collection (Ab Rahman et al., 2012; Bakar \& Abdghani, 2011; Muda et al., 2009; Nadzri et al., 2012; Wahab et al., 2012; Wahid \& Kader, 2010). However, from the context of Indonesia, research studies have focused on the strategic model to increase the efficiency of zakat through zakat management system and poverty control (Manara et al., 2018), mobilization of zakat payments (Doktoralina et al., 2018), zakat management system in contemporary Indonesian economy (Adachi, 2018), Shariah governance compliance for zakat management (Hakim et al., 2019), fund raising to optimize zakat collections (Bidin et al., 2009; Grais \& Pellegrini, 2006; Idris et al., 2012; Kasri \& Putri, 2018) and efficiency of zakat collection institutions in Indonesia (Lessy, 2009; Siswantoro \& Dewi, 2007; Siswantoro \& Nurhayati, 2012) . Besides, research work conducted by Doktoralina et al. (2018) has observed the accounting zakat and its role in the field of supply chain management in Islamic economy. Authors have claimed that zakat can play its significant role as support function in supply chain literature. Findings of their study reveal that there is a significant need to reconsider the various Islamic concepts to get more benefits from Islamic finance.

\section{Methods and variables of the study}

For better understanding, this study has adopted the primary data collection measure in the form of questionnaire to get the significant responses from the targeted respondents in the region of Indonesia. In the very first step, questionnaire is developed while taking zakat collection and distribution as major explanatory variables. For zakat collection system and its efficiency measurement, seven items are added to the questionnaire covering the title of ZCF1 to ZCF7. For zakat distribution six items under the title of ZDF1 to ZDF6 are considered for which the details are given under the results and discussion portion. For economic output, ten items are added, covering the title of increasing economic prosperity, increasing social wellbeing, cleanliness of wealth, right people to get the portion of zakat in the economy, social growth and economic wellbeing, increasing growth rate in the economy through better living for poor/needy, equal distribution of wealth, helping needy students for better educational facility, helping needy students for better educational facility, and Provision of good health facilities through zakat bases health centers, ranging from EIMP1 to EIMP10. A sample of 362 respondents is finally observed for descriptive, correlation and regression analysis of the study. Descriptive analysis provides the overview about the dataset, correlation indicates the association between the variables, while regression analysis explains the causal association between dependent and independent variables of the study.

\section{Results and Discussion}

Table 1 shows descriptive facts, mean score, status of the mean score on Likert scale, standard deviation, minimum and maximum score with the sample respondents. It is observed that most of the indicators have shown their average score above four, reflecting the point of strongly agree on five points Likert scale. For common understanding, those items having mean score of above 4.50 are scaled as strongly agree and those below 4.50 but equal to 4 are scaled as "agree" on the Likert scale. Maximum mean value is observed for ZCF5 which measures the fact that efficient serving the zakat collection system in local region of Indonesia. The $2^{\text {nd }}$ highest mean score is associated with ZCF3 which shows good satisfaction level when payment is made to zakat collection center in the local area 
of Indonesia. For zakat distribution ZD, the highest mean score is observed for ZDF2 which specifies that efficient distribution of zakat is found in local community of Indonesia. For the factors of economic impact of zakat collection and distribution, the highest mean score is observed for EIMP6 which is 4.561 and for EIMP5, respectively. All the items under Table 1 also present the values of the standard deviation which are above 1 but less than 2 .

\section{Table 1}

Descriptive Statistics

\begin{tabular}{|c|c|c|c|c|c|c|}
\hline Variable & Obs & Mean & Status on Likert Scale & Std.Dev. & Min & Max \\
\hline ZCF1 & 362 & 4.793 & Strongly agree & 1.126 & 1 & 5 \\
\hline ZCF2 & 362 & 4.569 & Strongly agree & 1.069 & 1 & 5 \\
\hline ZCF3 & 362 & 4.815 & Strongly agree & 1.12 & 1 & 5 \\
\hline ZCF4 & 362 & 4.033 & Agree & 1.278 & 1 & 5 \\
\hline ZCF5 & 362 & 4.981 & Strongly agree & 1.206 & 1 & 5 \\
\hline ZCF6 & 362 & 4.674 & Strongly agree & 1.169 & 1 & 5 \\
\hline ZCF7 & 362 & 3.818 & Agree & 1.129 & 1 & 5 \\
\hline ZDF1 & 362 & 4.787 & Strongly agree & 1.127 & 1 & 5 \\
\hline ZDF2 & 362 & 4.82 & Strongly agree & 1.26 & 1 & 5 \\
\hline ZDF3 & 362 & 4.564 & Strongly agree & 1.077 & 1 & 5 \\
\hline ZDF4 & 362 & 4.558 & Strongly agree & 1.054 & 1 & 5 \\
\hline ZDF5 & 362 & 4.34 & Agree & 1.009 & 1 & 5 \\
\hline ZDF6 & 362 & 4.699 & Strongly agree & 1.141 & 1 & 5 \\
\hline EIMP1 & 362 & 4.149 & Agree & 1.089 & 1 & 5 \\
\hline EIMP2 & 362 & 4.492 & Agree & 1.137 & 1 & 5 \\
\hline EIMP3 & 362 & 4.597 & Strongly agree & 1.041 & 1 & 5 \\
\hline EIMP4 & 362 & 3.434 & Strongly agree & .986 & 1 & 5 \\
\hline EIMP5 & 362 & 4.461 & Agree & 1.021 & 1 & 5 \\
\hline EIMP6 & 362 & 4.561 & Strongly agree & 1.025 & 1 & 5 \\
\hline EIMP7 & 362 & 4.094 & Agree & 1.103 & 1 & 5 \\
\hline EIMP8 & 362 & 3.92 & Near to agree & 1.054 & 1 & 5 \\
\hline EIMP9 & 362 & 4.525 & Strongly agree & 1.107 & 1 & 5 \\
\hline EIMP10 & 362 & 4.359 & agree & 1.169 & 1 & 5 \\
\hline
\end{tabular}

Table 2 shows the correlation matrix between the variables items of independent variables; zakat collection and distribution system in the region of Indonesia. It is observed that correlation between ZCF1 and ZCF2 is .434 indicating a moderate level of association. While correlation between ZCF3 and ZCF1 is 56.7 indicating an above average association. The rest of the other indicators present low and moderate level of relationship with each other. To identify either the correlation between these items is problematic or not, variance inflation factor test is applied which represents individual VIF, $1 /$ VIF and mean score of VIF for all the items, having good correlation. It is observed that ZCF5 and ZCF3 have a VIF score of 2.161 and 2.125. While for other items this tolerance score is below 2. By the end of Table 3, mean VIF score of 1.765 shows that there is no problem for higher correlation between the stated items, hence considered for the regression analysis to study the impact of zakat collection and distribution on the economy of Indonesia.

Table 2

Correlation Matrix

\begin{tabular}{|c|c|c|c|c|c|c|c|c|c|c|c|c|c|}
\hline VARIABLES & (1) & (2) & (3) & (4) & (5) & (6) & (7) & (8) & (9) & (10) & (11) & (12) & (13) \\
\hline (1) ZCF1 & 1.000 & & & & & & & & & & & & \\
\hline (2) $\mathrm{ZCF} 2$ & 0.434 & 1.000 & & & & & & & & & & & \\
\hline (3) $\mathrm{ZCF} 3$ & 0.567 & 0.428 & 1.000 & & & & & & & & & & \\
\hline (4) ZCF4 & 0.011 & 0.252 & 0.078 & 1.000 & & & & & & & & & \\
\hline (5) ZCF5 & 0.493 & 0.397 & 0.549 & 0.014 & 1.000 & & & & & & & & \\
\hline (6) ZCF6 & 0.386 & 0.342 & 0.462 & 0.068 & 0.481 & 1.000 & & & & & & & \\
\hline (7) ZCF7 & 0.419 & 0.359 & 0.460 & 0.102 & 0.596 & 0.450 & 1.000 & & & & & & \\
\hline (8) ZDF 1 & 0.415 & 0.420 & 0.491 & 0.124 & 0.458 & 0.494 & 0.401 & 1.000 & & & & & \\
\hline (9) $\mathrm{ZDF} 2$ & 0.399 & 0.481 & 0.347 & 0.086 & 0.461 & 0.357 & 0.454 & 0.398 & 1.000 & & & & \\
\hline (10) ZDF3 & 0.343 & 0.377 & 0.445 & 0.224 & 0.347 & 0.232 & 0.310 & 0.332 & 0.322 & 1.000 & & & \\
\hline (11) ZDF4 & 0.420 & 0.496 & 0.491 & 0.165 & 0.333 & 0.370 & 0.237 & 0.475 & 0.320 & 0.391 & 1.000 & & \\
\hline (12) ZDF5 & 0.370 & 0.542 & 0.353 & 0.195 & 0.395 & 0.240 & 0.373 & 0.300 & 0.436 & 0.494 & 0.400 & 1.000 & \\
\hline (13) ZDF6 & 0.374 & 0.454 & 0.438 & 0.094 & 0.473 & 0.269 & 0.351 & 0.348 & 0.463 & 0.375 & 0.426 & 0.537 & 1.000 \\
\hline
\end{tabular}


Table 3

Variance inflation factor

\begin{tabular}{lrrlrr}
\hline & VIF & 1/VIF & VIF & $1 /$ VIF \\
\hline ZCF5 & 2.161 & .463 & ZCF1 & 1.746 & .573 \\
ZCF3 & 2.125 & .471 & ZDF1 & 1.723 & .58 \\
ZDF5 & 1.921 & .521 & ZDF2 & 1.672 & .598 \\
ZCF2 & 1.914 & .523 & ZCF6 & 1.62 & .617 \\
ZCF7 & 1.83 & .546 & ZDF3 & 1.559 & .641 \\
ZDF6 & 1.766 & .566 & ZCF4 & 1.153 & .867 \\
ZDF4 & 1.755 & .57 & MEAN VIF & 1.765 &. \\
\hline
\end{tabular}

Table 4 presents the regression findings for the economic impact of zakat collection and distribution in the region of Indonesia. It is observed that the factor of the presence of zakat collection center has its positive influence on the value of social well-being in Indonesia. This effect implies that with the presence of more collection center of zakat in Indonesia, more social wellbeing will be experienced, accordingly. The rest of the indicators from the economy are found to be insignificantly associated with the presence of zakat collection center. The $2^{\text {nd }}$ indicator for zakat collection is measured through its smooth working. It is found that smooth working of zakat collection system has its own significant and positive influence on economic prosperity in Indonesia. The coefficient of .220 is significant at 1 percent, which means that there is a significant and positive association between the working of zakat collection system and economic performance in Indonesia. ZCF3 or proper network of zakat collection indicates its positive impact of right distribution of zakat to needy people and social growth with economic wellbeing as well. This effect is significant at 5 and 1 percent level of significance. Through efficient serving of zakat collection center, it is observed that right distribution of zakat is possible, and this claim is accepted at 5 percent significance level with the coefficient of .0805 and standard error of 0.0380 , respectively. Social awareness in the local community indicates its positive impact of .176 on cleanliness of the wealth for local individuals. With the good satisfaction level of payment for the zakat at local collection center, respondents believe that it will take to the cleanliness of their wealth with the coefficient of .146 and for social growth, its effect is .162, respectively. After the collection center, the effect of distribution system on the economy is observed. It is extracted that with the quality distribution of zakat in the local area of Indonesia, right distribution of zakat and social growth with economic wellbeing will be observed. One of the most significant contribution in zakat distribution system is found through mosques and local community center. It is found that both mosque and Muslim community centers are positively affecting the zakat distribution which in return leads towards increasing economic prosperity, increasing social wellbeing, cleanliness of the wealth, right distribution of zakat and social growth and economic wellbeing is found. It means that the first five indicators for economic impact of zakat distribution are significantly and positive affected by the role of mosques and Islamic centers in Indonesia. While the factor of overall management system of zakat in the local economy has its own positive influence on the right distribution and the social growth factors. Additionally, findings through regression analysis under Table 4 indicates that more distribution system can lead to positive influence on increasing social wellbeing, cleanliness of wealth and social growth with economic welling.

Table 4 presents the effect of zakat collection and distribution as the $2^{\text {nd }}$ five measures of economy. It is observed that the presence of proper zakat collection center has its own positive and significant influence on the provision of good health facilities to the needy individuals in Indonesia. Besides, ZCF1 has presented its own direct influence on the growth rate in the economy through provision of better standards of living. This effect is significantly positive at 1 percent level of significance. ZCF2 impact on provision of good health facilities is also significantly positive with the coefficient of .146 and standard error of .0725 . Meanwhile, the idea of proper network of zakat collection has its direct influence on equal distribution of wealth and helping the needy students for better education in the society. It means that when the network of zakat collection is improved, it will directly affect the education system in a positive way and equal distribution of wealth in the society as well. 
Table 4

Regression findings for economic impact of zakat collection and Distribution

\begin{tabular}{|c|c|c|c|c|c|}
\hline VARIABLES/Items & $\begin{array}{c}\text { (1) } \\
\text { Increasing } \\
\text { economic } \\
\text { prosperity }\end{array}$ & $\begin{array}{c}(2) \\
\text { Increasing } \\
\text { social } \\
\text { wellbeing }\end{array}$ & $\begin{array}{c}\text { (3) } \\
\text { Cleanliness of } \\
\text { the wealth }\end{array}$ & $\begin{array}{c}(4) \\
\text { Right } \\
\text { distribution of } \\
\text { zakat } \\
\end{array}$ & $\begin{array}{l}\quad(5) \\
\text { Social growth } \\
\text { and economic } \\
\text { well being }\end{array}$ \\
\hline $\begin{array}{l}\text { Presence of proper zakat collection }(\mathrm{ZC}) \\
\text { center in your region: } \mathbf{Z C F} 1\end{array}$ & -0.00364 & $0.173 * * *$ & 0.0215 & -0.0161 & 0.0459 \\
\hline $\begin{array}{l}\text { Zakat collection center is working in a } \\
\text { smooth way in my community: ZCF2 }\end{array}$ & $\begin{array}{l}(0.0729) \\
0.220 * * *\end{array}$ & $\begin{array}{l}(0.0582) \\
-0.0643\end{array}$ & $\begin{array}{l}(0.0519) \\
0.115^{* *}\end{array}$ & $\begin{array}{c}(0.0553) \\
0.0605\end{array}$ & $\begin{array}{l}(0.0540) \\
-0.00650\end{array}$ \\
\hline $\begin{array}{l}\text { There is proper network of zakat } \\
\text { collection in my residing area:ZCF3 }\end{array}$ & $\begin{array}{c}(0.0695) \\
-0.119\end{array}$ & $\begin{array}{c}(0.0658) \\
0.0542\end{array}$ & $\begin{array}{c}(0.0559) \\
0.0530\end{array}$ & $\begin{array}{l}(0.0659) \\
0.150^{* *}\end{array}$ & $\begin{array}{l}(0.0621) \\
0.211^{* * *}\end{array}$ \\
\hline $\begin{array}{l}\text { serving of zakat collection system is very } \\
\text { efficient: ZCF } 4\end{array}$ & $\begin{array}{c}(0.0726) \\
-0.0268\end{array}$ & $\begin{array}{l}(0.0635) \\
-0.0556\end{array}$ & $\begin{array}{c}(0.0586) \\
-0.0594\end{array}$ & $\begin{array}{l}(0.0662) \\
0.0805 * *\end{array}$ & $\begin{array}{c}(0.0617) \\
-0.0357\end{array}$ \\
\hline $\begin{array}{l}\text { Social awareness in the local community } \\
\text { could add more collection of zakat: } \\
\text { ZCF5 }\end{array}$ & $\begin{array}{l}(0.0529) \\
-0.112 *\end{array}$ & $\begin{array}{l}(0.0372) \\
-0.0888\end{array}$ & $\begin{array}{l}(0.0361) \\
0.176^{* * *}\end{array}$ & $\begin{array}{l}(0.0380) \\
-0.0876\end{array}$ & $\begin{array}{l}(0.0357) \\
-0.0490\end{array}$ \\
\hline $\begin{array}{l}\text { Overall collection system is equipped } \\
\text { with good serving setup :ZCF6 }\end{array}$ & $\begin{array}{c}(0.0648) \\
-0.0235\end{array}$ & $\begin{array}{l}(0.0549) \\
0.00928\end{array}$ & $\begin{array}{l}(0.0608) \\
0.00244\end{array}$ & $\begin{array}{r}(0.0590) \\
0.00202\end{array}$ & $\begin{array}{c}(0.0612) \\
0.0697\end{array}$ \\
\hline $\begin{array}{l}\text { My satisfaction level is good whenever in } \\
\text { went for the payment of zakat } \\
\text { :ZCF7 }\end{array}$ & $\begin{array}{l}(0.0555) \\
-0.0140\end{array}$ & $\begin{array}{c}(0.0527) \\
0.0391\end{array}$ & $\begin{array}{l}(0.0481) \\
0.146 * *\end{array}$ & $\begin{array}{l}(0.0460) \\
0.000537\end{array}$ & $\begin{array}{l}(0.0473) \\
0.162 * * *\end{array}$ \\
\hline $\begin{array}{l}\text { I have no doubt for the quality } \\
\text { distribution of zakat in my region :ZDF1 }\end{array}$ & $\begin{array}{l}(0.0620) \\
0.139 * *\end{array}$ & $\begin{array}{l}(0.0549) \\
-0.00701\end{array}$ & $\begin{array}{l}(0.0587) \\
0.00747\end{array}$ & $\begin{array}{l}(0.0534) \\
0.172 * * *\end{array}$ & $\begin{array}{l}(0.0511) \\
0.165^{* * *}\end{array}$ \\
\hline $\begin{array}{l}\text { Distribution of zakat is very efficient as it } \\
\text { found to be depending on the proper } \\
\text { collection:ZDF2 }\end{array}$ & $\begin{array}{c}(0.0638) \\
0.0136\end{array}$ & $\begin{array}{c}(0.0491) \\
0.0545\end{array}$ & $\begin{array}{c}(0.0523) \\
0.0780\end{array}$ & $\begin{array}{l}(0.0582) \\
-0.0691\end{array}$ & $\begin{array}{l}(0.0574) \\
0.00304\end{array}$ \\
\hline $\begin{array}{l}\text { Social and print media are key sources of } \\
\text { information for zakat payment and its } \\
\text { distribution: ZDF3 }\end{array}$ & $\begin{array}{c}(0.0556) \\
0.0582\end{array}$ & $\begin{array}{l}(0.0466) \\
-0.0262\end{array}$ & $\begin{array}{c}(0.0573) \\
0.0352\end{array}$ & $\begin{array}{c}(0.0505) \\
0.139\end{array}$ & $\begin{array}{l}(0.0472) \\
-0.00950\end{array}$ \\
\hline $\begin{array}{l}\text { Mosques and muslim community centers } \\
\text { are key role players for proper } \\
\text { distribution of zakat:ZDF4 }\end{array}$ & $\begin{array}{l}(0.0750) \\
0.188^{* *}\end{array}$ & $\begin{array}{l}(0.0540) \\
0.0986^{*}\end{array}$ & $\begin{array}{l}(0.0641) \\
0.193 * * *\end{array}$ & $\begin{array}{l}(0.6350) \\
0.6331^{* *}\end{array}$ & $\begin{array}{l}(0.0584) \\
0.186 * * *\end{array}$ \\
\hline $\begin{array}{l}\text { Overall management system of zakat is } \\
\text { good in our economy: ZDF5 }\end{array}$ & $\begin{array}{c}(0.0760) \\
0.0629\end{array}$ & $\begin{array}{c}(0.0583) \\
0.0917\end{array}$ & $\begin{array}{l}(0.0621) \\
-0.0213\end{array}$ & $\begin{array}{l}(0.0626) \\
0.264 * * *\end{array}$ & $\begin{array}{l}(0.0659) \\
0.159 * * *\end{array}$ \\
\hline $\begin{array}{l}\text { There must be some more distribution } \\
\text { system for the better facilities to the } \\
\text { poor:ZDF6 }\end{array}$ & $\begin{array}{c}(0.0725) \\
-0.0348\end{array}$ & $\begin{array}{l}(0.0714) \\
0.483 * * *\end{array}$ & $\begin{array}{l}(0.0632) \\
0.213 * * *\end{array}$ & $\begin{array}{c}(0.0636) \\
0.0881\end{array}$ & $\begin{array}{l}(0.0594) \\
0.143^{* *}\end{array}$ \\
\hline Constant & $\begin{array}{c}(0.0649) \\
1.962 * * * \\
(0.324)\end{array}$ & $\begin{array}{c}(0.0598) \\
0.663^{* *} \\
(0.266)\end{array}$ & $\begin{array}{c}(0.0590) \\
1.077 * * * \\
(0.250)\end{array}$ & $\begin{array}{c}(0.0601) \\
1.176^{* * *} \\
(0.255)\end{array}$ & $\begin{array}{c}(0.0572) \\
0.849^{* * *} \\
(0.224)\end{array}$ \\
\hline Observations & 362 & 362 & 362 & 362 & 362 \\
\hline R-squared & 0.141 & 0.430 & 0.377 & 0.330 & 0.407 \\
\hline
\end{tabular}

Social awareness in the local community leads towards the provision of good health facilities for the needy individuals. While the factor of overall collection system equipped with good serving setup has its own direct influence on increasing growth rate, gap minimization between rich and poor and provision of good health facilities to the individuals. In addition, factor of good satisfaction level also has its own positive influence on the provision of educational facilities to the students. From the perspective of distribution system, it is found that the role of social and print media is found to be significantly positive on growth rate, equal distribution of wealth and gap minimization between rich and poor. In addition, Mosques and Muslim community centers in zakat distribution system also have significantly positive effects for lowering the gap between rich and poor. Besides, overall distribution system of zakat is only found to be significantly positive for provision of good health facilities in the region of Indonesia. In the last, it is believed that more distribution for better facilities to the poor may lead towards increasing growth rate and helping the needy students in education. 
Table 4

Regression findings for economic impact of zakat collection and Distribution (Continued)

\begin{tabular}{|c|c|c|c|c|c|}
\hline VARIABLES & $\begin{array}{c}\text { (1) } \\
\text { Increasing growth } \\
\text { rate in the economy } \\
\text { through better } \\
\text { living for } \\
\text { poor/needy }\end{array}$ & $\begin{array}{c}\text { (2) } \\
\text { Equal } \\
\text { distribution } \\
\text { of wealth }\end{array}$ & $\begin{array}{l}(3) \\
\text { Helping needy } \\
\text { students for } \\
\text { better } \\
\text { educational } \\
\text { facility }\end{array}$ & $\begin{array}{l}\text { (4) } \\
\text { Minimizing the } \\
\text { gap between rich } \\
\text { and poor in the } \\
\text { economy }\end{array}$ & $\begin{array}{c}(5) \\
\text { Provision of } \\
\text { good health } \\
\text { facilities through } \\
\text { zakat bases } \\
\text { health center }\end{array}$ \\
\hline $\begin{array}{l}\text { Presence of proper zakat } \\
\text { collection (ZC) center in } \\
\text { your region: ZCF1 }\end{array}$ & $0.188 * * *$ & 0.0387 & -0.0201 & 0.0378 & $0.146^{* *}$ \\
\hline $\begin{array}{l}\text { Zakat collection center is } \\
\text { working in a smooth way in } \\
\text { my community: } \mathbf{Z C F 2}\end{array}$ & $\begin{array}{c}(0.0550) \\
0.110\end{array}$ & $\begin{array}{l}(0.0576) \\
0.00532\end{array}$ & $\begin{array}{c}(0.0555) \\
0.0415\end{array}$ & $\begin{array}{l}(0.0582) \\
-0.00668\end{array}$ & $\begin{array}{l}(0.0625) \\
0.146 * *\end{array}$ \\
\hline $\begin{array}{l}\text { There is proper network of } \\
\text { zakat collection in my } \\
\text { residing area:ZCF3 }\end{array}$ & $\begin{array}{c}(0.0584) \\
0.0385\end{array}$ & $\begin{array}{l}(0.0588) \\
0.175 * *\end{array}$ & $\begin{array}{l}(0.0569) \\
0.307 * * *\end{array}$ & $\begin{array}{c}(0.0768) \\
0.0996\end{array}$ & $\begin{array}{l}(0.0725) \\
-0.0393\end{array}$ \\
\hline $\begin{array}{l}\text { serving of zakat collection } \\
\text { system is very efficient: } \\
\text { ZCF4 }\end{array}$ & $\begin{array}{l}(0.0603) \\
-0.0415\end{array}$ & $\begin{array}{c}(0.0715) \\
0.0180\end{array}$ & $\begin{array}{l}(0.0582) \\
0.00380\end{array}$ & $\begin{array}{l}(0.0676) \\
-0.0469\end{array}$ & $\begin{array}{l}(0.0734) \\
-0.0235\end{array}$ \\
\hline $\begin{array}{l}\text { Social awareness in the } \\
\text { local community could add } \\
\text { more collection of zakat: } \\
\text { ZCF5 }\end{array}$ & $\begin{array}{l}(0.0363) \\
-0.0924\end{array}$ & $\begin{array}{c}(0.0368) \\
0.0252\end{array}$ & $\begin{array}{c}(0.0365) \\
0.0635\end{array}$ & $\begin{array}{c}(0.0468) \\
0.0659\end{array}$ & $\begin{array}{l}(0.0540) \\
0.211 * * *\end{array}$ \\
\hline $\begin{array}{l}\text { Overall collection system is } \\
\text { equipped with good serving } \\
\text { setup :ZCF6 }\end{array}$ & $\begin{array}{l}(0.0579) \\
0.122 * * *\end{array}$ & $\begin{array}{c}(0.0668) \\
0.0659\end{array}$ & $\begin{array}{l}(0.0610) \\
-0.0325\end{array}$ & $\begin{array}{l}(0.0688) \\
0.0914^{*}\end{array}$ & $\begin{array}{c}(0.0760) \\
0.106^{*}\end{array}$ \\
\hline $\begin{array}{l}\text { My satisfaction level is } \\
\text { good whenever in went for } \\
\text { the payment of zakat } \\
\text { :ZCF7 }\end{array}$ & $\begin{array}{l}(0.0441) \\
-0.0278\end{array}$ & $\begin{array}{c}(0.0482) \\
0.0408\end{array}$ & $\begin{array}{l}(0.0451) \\
0.167 * * *\end{array}$ & $\begin{array}{c}(0.0525) \\
0.0741\end{array}$ & $\begin{array}{c}(0.0628) \\
0.0970\end{array}$ \\
\hline $\begin{array}{l}\text { I have no doubt for the } \\
\text { quality distribution of zakat } \\
\text { in my region :ZDF1 }\end{array}$ & $\begin{array}{c}(0.0515) \\
0.0518\end{array}$ & $\begin{array}{c}(0.0545) \\
0.0833\end{array}$ & $\begin{array}{l}(0.0552) \\
-0.0547\end{array}$ & $\begin{array}{l}(0.0599) \\
0.186^{* *}\end{array}$ & $\begin{array}{l}(0.0649) \\
0.152 * *\end{array}$ \\
\hline $\begin{array}{l}\text { Distribution of zakat is very } \\
\text { efficient as it found to be } \\
\text { depending on the proper } \\
\text { collection:ZDF2 }\end{array}$ & $\begin{array}{c}(0.0531) \\
0.0491\end{array}$ & $\begin{array}{l}(0.0626) \\
0.0869 * *\end{array}$ & $\begin{array}{l}(0.0507) \\
0.164 * * *\end{array}$ & $\begin{array}{l}(0.0727) \\
0.147 * * *\end{array}$ & $\begin{array}{l}(0.0738) \\
-0.0819\end{array}$ \\
\hline $\begin{array}{l}\text { Social and print media are } \\
\text { key sources of information } \\
\text { for zakat payment and its } \\
\text { distribution: ZDF3 }\end{array}$ & $\begin{array}{c}(0.0437) \\
0.106^{*}\end{array}$ & $\begin{array}{l}(0.0436) \\
0.270 * * *\end{array}$ & $\begin{array}{c}(0.0508) \\
0.0905\end{array}$ & $\begin{array}{c}(0.0497) \\
0.124^{*}\end{array}$ & $\begin{array}{l}(0.0529) \\
-0.0102\end{array}$ \\
\hline $\begin{array}{l}\text { Mosques and muslim } \\
\text { community centers are key } \\
\text { role players for proper } \\
\text { distribution of zakat:ZDF4 }\end{array}$ & $\begin{array}{c}(0.0567) \\
0.0238\end{array}$ & $\begin{array}{c}(0.0681) \\
0.0440\end{array}$ & $\begin{array}{l}(0.0567) \\
-0.0435\end{array}$ & $\begin{array}{l}(0.0716) \\
0.135 * *\end{array}$ & $\begin{array}{l}(0.0713) \\
-0.0614\end{array}$ \\
\hline $\begin{array}{l}\text { overall management system } \\
\text { of zakat is good in our } \\
\text { economy: ZDF5 }\end{array}$ & $\begin{array}{c}(0.0583) \\
0.229\end{array}$ & $\begin{array}{l}(0.0606) \\
0.00866\end{array}$ & $\begin{array}{l}(0.0531) \\
-0.0488\end{array}$ & $\begin{array}{c}(0.0682) \\
0.0646\end{array}$ & $\begin{array}{l}(0.0713) \\
0.238 * * *\end{array}$ \\
\hline $\begin{array}{l}\text { there must be some more } \\
\text { distribution system for the } \\
\text { better facilities to the } \\
\text { poor:ZDF6 }\end{array}$ & $\begin{array}{c}(0.647) \\
0.257 * * *\end{array}$ & $\begin{array}{c}(0.0642) \\
0.0781\end{array}$ & $\begin{array}{l}(0.0588) \\
0.167 * * *\end{array}$ & $\begin{array}{c}(0.0711) \\
0.0408\end{array}$ & $\begin{array}{l}(0.0830) \\
0.00617\end{array}$ \\
\hline Constant & $\begin{array}{c}(0.0609) \\
0.683 * * * \\
(0.207)\end{array}$ & $\begin{array}{l}(0.0566) \\
0.623 * \\
(0.355)\end{array}$ & $\begin{array}{c}(0.0573) \\
0.851^{* * *} \\
(0.287)\end{array}$ & $\begin{array}{c}(0.0619) \\
0.857 * * * \\
(0.252)\end{array}$ & $\begin{array}{c}(0.0623) \\
1.762 * * * \\
(0.367)\end{array}$ \\
\hline Observations & 362 & 362 & 362 & 362 & 362 \\
\hline R-squared & 0.427 & 0.437 & 0.472 & 0.308 & 0.147 \\
\hline
\end{tabular}

\section{Conclusions and Recommendations}

This study has examined the effect of collection and distribution of zakat in the region of Indonesia for their economic outcomes. A sample from various individuals dealing with the payment of zakat in various regions is selected. For zakat collection and system management, seven dimensions were selected, and for zakat distribution six dimensions were added in the model. For economic outcome, 
overall ten items were observed for the study. Findings through regression analysis have indicated the fact that zakat collection center has its own significant impact on social wellbeing and smooth working of collection department has a significant influence on cleanliness of wealth. In addition, factors like network of zakat collection indicate their significant and positive influence on right distribution of zakat and social growth with economic development. Provision of social awareness about zakat collection can lead towards more cleanliness of the wealth. Besides, some more distribution system with better facilities has its own significant and positive influence increasing economic prosperity, increasing social wellbeing, cleanliness of wealth, right distribution of zakat and social growth with economic wellbeing. For the $2^{\text {nd }}$ five measures of economic output, factor of zakat collection center indicates its own significant and positive impact on increasing growth rate and provision of good health facilities through zakat payments. Proper distribution through collections system leads towards equal distribution of wealth, helping needy students in educational facilities, and minimizing gap between rich and poor. Additionally, more distribution network indicates its own significant and positive influence on increasing growth rate, and helping the needy student in education. These findings have provided a significant contribution in the literature of zakat, its collection and distribution from supply chain perspective as both components have shown their reasonable importance in overall zakat management system by local government of Indonesia. The economic output through both collection and distribution of zakat is a significant addition in the literature of Islamic finance as such studies as much need of time to fill the relevant gap. Country representatives could find the positive association between zakat collection and distribution system on the economy for better strategic decision in future. Although, more collection and distribution networks are suggested by the respondents, yet the existing one provides its good services. Furthermore, the present study is very useful for the students of Islamic finance and its association with the economy as reasonable justification is provided through empirical facts. Although study has provided some good addition in the contemporary literature, yet some limitations need to be readdressed in future. First, the study has provided a limited context of zakat collection and distribution which could be expanded while adding the latest policies being adopted by the local government and their economic impact. Second, future studies could be reconsidered through getting the significant responses from those who are directly linked to the collection and distribution of zakat as they have much more body of knowledge about their economic implications.

\section{References}

Ab Rahman, A., Alias, M. H., \& Omar, S. M. N. S. (2012). Zakat institution in Malaysia: Problems and issues. Global Journal of Al-Thalaqah, 2(1), 35-42.

Adachi, M. (2018). Discourses of Institutionalization of Zakat Management System in Contemporary Indonesia: Effect of the Revitalization of Islamic Economics. International Journal of Zakat, 3(1), 25-35.

Ahmad, I. H., \& Ma'in, M. (2014). The Efficiency of Zakat Collection and Distribution: Evidence from Two Stage Analysis. Journal of Economic Cooperation \& Development, 35(3).

Ali, I., \& Hatta, Z. A. (2014). Zakat as a Poverty Reduction Mechanism Among the M uslim Community: Case Study of B angladesh, M alaysia, and I ndonesia. Asian Social Work and Policy Review, 8(1), 59-70.

Ali, K., Khan, Z., \& Saleh, A. (2016). Islamic Versus Conventional Banking: An Insight into the Malaysian Dual Banking System. Asian Journal of Economics and Empirical Research, 3(1), 103112.

Bakar, M. H. A., \& Abdghani, A. H. (2011). Towards achieving the quality of life in the management of zakat distribution to the rightful recipients (the poor and needy). International Journal of Business and Social Science, 2(4).

Bidin, Z., Idris, K. M., \& Shamsudin, F. M. (2009). Predicting compliance intention on zakah on employment income in Malaysia: An application of reasoned action theory. Jurnal Pengurusan (UKM Journal of Management), 28. 
Bittar, M. L. (2017). The Effect of Personal Factors on the Customer Rating of the Quality of Services of the Islamic Banks Operating in the Syrian Coast. International Journal of Business, Economics and Management, 4(1), 16-25.

Doktoralina, C. M., Bahari, Z., \& Abdullah, S. R. (2018). Mobilisation of Income Zakat Payment In Indonesia. Ikonomika, 3(2), 189-204.

Doktoralina, C. M., Bahari, Z., Herliansyah, Y., Ismail, N. A., \& Putri, P. P. (2018). Role of Accounting Zakat as a Support Function in Supply Chain Management: A Resurrection of the Islamic Economy. International Journal of Supply Chain Management, 7(5), 336.

Grais, W., \& Pellegrini, M. (2006). Corporate governance and Shariah compliance in institutions offering Islamic financial services. The World Bank.

Hakim, C. M., Beik, I. S., Pramono, S. E., \& Saoqi, A. A. Y. (2019). Designing Shariah Governance Standard for Zakat Management Organization: Indonesia Experience. Working Papers-Puskas Baznas.

Hammoud, N., \& Bittar, M. (2016). Measuring the Quality of Islamic Banks' Services and Its Impact on Customers' Satisfaction-A Survey Study on The Islamic Banks' Customers in Lattakia, Syria. International Journal of Business, Economics and Management, 3(1), 1-17.

Hassan, H. S., \& Alanazi, T. M. (2018). Roles of Islamic Business Ethics in the Formation of Internal Organisational Culture: A Qualitative Approach of Muslims' SMEs in the UK. International Journal of Economics, Business and Management Studies, 5(1), 16-30.

Havidz, S. A. H., \& Setiawan, C. (2015). A comparative study of efficiency between conventional and Islamic banks in Indonesia. Asian Economic and Financial Review, 5(5), 790-804.

Idris, K. M., Bidin, Z., \& Saad, R. A. J. (2012). Islamic religiosity measurement and its relationship with business income zakat compliance behavior. Jurnal Pengurusan (UKM Journal of Management), 34.

Javaid, S., \& Alalawi, S. (2018). Performance and profitability of Islamic banks in Saudi Arabia: An empirical analysis. Asian Economic and Financial Review, 8(1), 38-51.

Kaslam, S. (2009). Governing zakat as a social institution: The Malaysian perspective. Social and Management Research Journal, 6(1), 15-32.

Kasri, R. A., \& Putri, N. I. S. (2018). Fundraising strategies to optimize zakat potential in Indonesia: An exploratory qualitative study. Al-Iqtishad Journal of Islamic Economics, 10(1), 1-24.

Kuran, T. (1986). The economic system in contemporary Islamic thought: Interpretation and assessment. International Journal of Middle East Studies, 18(2), 135-164.

Lessy, Z. (2009). Zakat (alms-giving) management in Indonesia: Whose job should it be? La_Riba, $3(1), 106-119$.

Lewis, M. K. (2001). Islam and accounting. Paper presented at the Accounting forum.

Manara, A. S., Permata, A. R. E., \& Pranjoto, R. G. H. (2018). Strategy model for increasing the potential of zakat through the crowdfunding-zakat system to overcome poverty in Indonesia. International Journal of Zakat, 3(4), 17-31.

Muda, M., Marzuki, A., \& Shaharuddin, A. (2009). Factors influencing individual participation in zakat contribution: exploratory investigation.

Nadzri, F. A. A., Rahman, A., Rashidah, \& Omar, N. (2012). Zakat and poverty alleviation: Roles of zakat institutions in Malaysia. International Journal of Arts and Commerce, 1(7), 61-72.

Rahim, A., \& Rahman, A. (2007). Pre-requisites for effective integration of zakah into mainstream Islamic financial system in Malaysia.

Sarea, A. (2012). Zakat as a benchmark to evaluate economic growth: An alternative approach. International Journal of Business and Social Science, 3(18).

Siswantoro, D., \& Dewi, M. K. (2007). The effectiveness of waqf fund raising through mutual fund in Indonesia. Paper presented at the Singapore International Waqf Conference.

Siswantoro, D., \& Nurhayati, S. (2012). Factors affecting concern about zakat as a tax deduction in Indonesia. International Journal of Management and Business Research, 2(4), 293-312.

Sudibyo, B. (2017). Indonesia Zakat Outlook, (pp. 84). Indonesia 
Suprayitno, E., Aslam, M., \& Harun, A. (2017). Zakat and SDGs: Impact zakat on human development in the five states of Malaysia. International Journal of Zakat, 2(1), 61-69.

Wahab, N. A., Rahman, A., \& Rahim, A. (2012). Efficiency of zakat institutions in Malaysia: An application of data envelopment analysis. Journal of Economic Cooperation \& Development, 33(1).

Wahid, H., \& Kader, R. A. (2010). Localization of Malaysian zakat distribution: Perceptions of amil and zakat recipients. A Tawhidi Epistemology: Zakat and Waqf Economy. Ed. Abdul Ghafar Ismail et al. Bangi, 461-483.

Yusoff, M. B. (2011). Zakat expenditure, school enrollment, and economic growth in Malaysia. International Journal of Business and Social Science, 2(6), 175-181.

Zainal, H., Bakar, A. A., \& Saad, R. A. J. (2016). Reputation, satisfaction of zakat distribution, and service quality as determinant of stakeholder trust in zakat institutions. International Journal of Economics and Financial Issues, 6(7S).

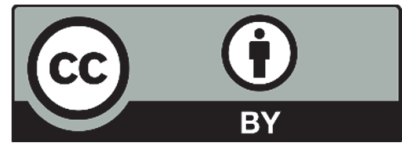

(C) 2019 by the authors; licensee Growing Science, Canada. This is an open access article distributed under the terms and conditions of the Creative Commons Attribution (CC-BY) license (http://creativecommons.org/licenses/by/4.0/). 